\title{
DEFINING THE GOALS IN OP "SCIENCE AND EDUCATION FOR SMART GROWTH" IN COMPLIANCE WITH THE NEEDS
}

\author{
Venelin Terziev ${ }^{1}$ and Margarita Bogdanova ${ }^{2}$ \\ ${ }^{1}$ Academician of the Russian Academy of Natural History, Moscow, Russia, Prof. D.Sc. (Ec.), \\ D.Sc. (National Security), D.Sc. (Social Activities), Ph.D., National Military University, Veliko \\ Tarnovo, Bulgaria; University of Rousse, Rousse, Bulgaria, terziev@skmat.com \\ ${ }^{2}$ Prof. Ph.D., D.A. Tsenov Academy of Economics, Svishtov, Bulgaria, \\ mbogdanova@uni-svishtov.bg
}

\begin{abstract}
The report presents a comparative analysis of different policies and approaches for management of centers of excellence (CoE) and centers of competence $(\mathrm{CoC})$ in the context of the convergence of science and technology policy. The potential challenges to its successful implementation in Bulgaria are outlined. Best practices and management models in the USA, UK, Denmark and Finland are discussed. Among the main problems in Bulgaria are the short horizon of integration between the efforts of universities and research organizations on the one hand, and business and public sector on the other, the lack of private investments for the development of research, the need for reforms in higher education aimed at improving the quality of education.
\end{abstract}

Keywords: Centers of excellence (CoE), Centers of competence $(\mathrm{CoC})$, convergence of scientific and technological policy.

\section{INTRODUCTION}

In the resent years, the subject of convergence in the scientific and the technological policy grows more and more topical and significant for the development of an economy and even society, based on knowledge. Universities' and research organizations' efforts integration on one hand, and of the businesses and the public sector's on the other hand, becomes a key circumstance for building capacity for innovations. According to some estimation, this is the third economic revolution in human history, which is expected to radically change the way of making business, the environment for living's qualities and the society as a whole.

In this complicated, dynamic environment, higher schools and the research organizations acquire bigger and bigger role of a motor and initiator of development. They are part of the "triple helix" that embraces the system „university - business - government”. They perform the so called „third mission”, directed towards encouraging the relations with users of knowledge and towards facilitating the technologies transfer. This 
new higher schools social role puts them in front of series of challenges that could be over taken through innovative approaches and use of all possible tools for facilitating the knowledge and technologies transfer.

The Centers of Excellence and the Centers of Competence, which are to be established in Bulgaria in the following years, are among the most modern possibilities for intervention up to now.

The topic about the Centers of Excellence (CoE) and Centers of Competence $(\mathrm{CoC})$ is perhaps the most update and significant for the higher schools at home to the very present moment. It is in the agenda of Operative Programme „Science and Education for Smart Growth“ (OP SESG) and of many higher schools that elaborate project documentation and prepare for managing multi-disciplinary research centers with high potential for scientific results in priority for the country subject fields.

That is why the scientific community's excitement and the expectations of all interested parties for the results and impact of this type of initiatives are great. Beside the planned direct results such as number of publications and hired researchers, in a longer term plan it is expected for the whole picture of scientific infrastructure to change, conditions for successful career for young researcher to be established and the significance of higher schools and research institutions for the development of economy based on knowledge to change.

\section{DEFINING THE GOALS IN OP SESG IN COMPLIANCE WITH THE NEEDS}

The analysis of scientific research status in the RB, made by the Ministry of Education and Science /MES/ outlines the weak aspects connected with the quality of services that the public participants in the sector of scientific researches render as well as the potential for development of researches and innovations. The weak cooperation with the business outlines as major problem in this field, and more particularly:

- Lack of coordinated policy of activities that regard scientific researches and innovations;

- Lack of modern scientific-innovation infrastructure;

- Fragmented institutional environment;

- Low share of financing on competitive indication and low total percentage of financing;

- Unfavourable age profile;

- Insufficient interaction between scientific-research organizations and companies.

Also available are strong aspects, on which an oriented towards the market change to be based on: good traditions in natural sciences, preserved scientific schools and high publication activity in some fields that have to deal with the newly emerging technologies (physics, chemistry, materials science, biochemistry and molecular biology, medicine, pharmaceutical and engineering sciences), cultural variety combined with specific national identity, strong researchers' orientation towards international cooperation, positive society's attitude regarding education and science. Despite that, these strong aspects have to be conformed to the goals and priority fields of ISSS for realizing the scientific-research system's innovation potential in the RB. Its adaptation and sustainability is what should be worked upon through stronger stress on the market signals and ways for attracting private investors.

OP SESG should play crucial role for improving SRDA level and innovations and for activating the innovation potential through supporting the pointed in ISSS ambition the RB to move from humble to the level of moderate innovator. For that purpose, the total level should be raised and the financial resources to be focused in the field of SRDA and innovations, in harmony with ISSS, which defines the following priority fields:

- Mechatronics and clean technologies;

- Informatics and ICT;

- Industry for healthy life and biotechnologies;

- New technologies in the creative and recreation industries.

That's why there is the identified need of system support of market-oriented scientific-research and development activities and of focusing the OP SESG financial interventions on the ISSS priority sectors in order to improve competitiveness of Bulgarian scientific-research system and of economy as a whole.

New and well equipped scientific-research infrastructures are important elements of ecosystems in the field of SRDA and innovations. The National Research Development Strategy 2020 (NRDS) analysis identifies the following negative trends in the status of scientific research infrastructure status in the RB: 
- Old equipment and ineffective use of existing equipment;

- Lack of advanced approach for administrative and financial management of existing infrastructure in basic organizations;

- Lack of professionally trained and qualified employees, who to work with the equipment and its users;

- Lack of the available modern equipment coordination and complementing within one organization or between the organizations;

- Lack of equipment concentration and, in some cases, highly individual approach and duplicating equipment.

Beside that, national bodies (Ministry of Education and Science, National Scientific Research Fund) have not established updated national roadmap for research infrastructure (NRMRI) containing basic information about scientific-research infrastructures such as, for example, availability of unique scientific-research tools, their territorial and institutional distribution, ownership (public or private), and conditions for clients' access yet. This lack of information impedes the effective infrastructure use and does not allow a clear picture of current status regarding the available infrastructures and the necessity for their development to be elaborated.

Scientific-research infrastructures modernization could have important positive effects in several aspects: improving the possibilities for cooperation between leading scientific organizations and the business; much higher quality of personnel's training in modern technologies; improving the possibilities for Bulgarian scientific teams participation in European networks for development of new technologies in the possible key fields that are defined as priority ones for the RB (ISSS) and for the whole EU. Heightened interest towards career in engineer, natural and medical sciences that are of decisive significance for the development of new technologies would be a substantial consequence of the improvement of scientific-research infrastructure and of the conditions for SRDA and innovations.

This shows the necessity of establishing and development of leading scientific-research centers, equipped with modern scientific infrastructure and equipment that are able to carry out scientific researches and innovations at the highest level at European level, with stress on the ISSS priority fields.

Scientific-research system in the RB is still highly concentrated in institutional and geographic aspect. The first five scientific-research organizations (all situated in the district of Sofia-city) produce about $75 \%$ of the total number of publications. The current scientific organizations map analysis reveals the following characteristics:

Most active in attracting financing ( $86 \%$ of the total amount of financing of Scientific-research activity in the RB) and in executing national and international projects are the scientific organizations in the district of Sofiacity - this includes the institutes of the Bulgarian Academy of Science, Saint Kliment Ohridski University of Sofia, Medical University of Sofia, Technical University of Sofia and few more. These organizations have various profiles of researches and active interaction with local and foreign companies.

Comparatively high activity and clear regional specialization is observed in the region of Plovdiv. Plovdiv is the second biggest Bulgarian city with predominantly agrifood and agricultural characteristics of its economic profile. The most active in the region are Paisiy Hilendarski University of Plovdiv, Medical University of Plovdiv and Plovdiv University of Food Technologies. The town of Stara Zagora is situated near Plovdiv, where smaller universities and organizations (e.g. the Thracian University and the institutes of the Agricultural Academy) satisfy mainly the needs of regional economy.

Third ranking region of knowledge and entrepreneur dynamics is Varna. Here the Technical University of Varna, the Medical University and the Institute of Oceanology to the Bulgarian Academy of Science report the best achievements in fields like quality of life, health and environment. The region is also of significance regarding the development of alternative energy sources and natural wealth preservation in the region of the Black Sea.

Some universities in Northern Bulgaria have significant capacity for participation in projects and infrastructures in the Danube Region Strategy in partnership with the business - mainly Angel Kanchev University of Ruse and the Pleven University of Medicine, which work in cooperation with institutions situated in Sofia and Plovdiv. No clear specialization of scientific organizations and their cooperation with business is visible in the rest of the districts in the RB.

OP SESG and OP "Innovations and Competitiveness" (OPIC), through systematic and purposeful interventions for encouraging regional specialization and integration of scientific organizations and main 
economic subjects in the ISSS priority fields, could significantly support the overall economic development of the regions outside Sofia.

In this context, it is of decisive significance that the regional scientific-research infrastructures and universities should not be observed as isles for academic and fundamental research but potentially strong participants in local economy, including regarding employment and industry. They should become key players of regional specialization and to build capacity for cooperation with business in ISSS priority fields.

Hence, a necessity of systems and purposeful actions for encouraging regional intelligent specialization and integration of scientific organizations and key subjects is defined, aiming improvement of the overall economic development in the districts outside the city of Sofia.

Some current needs could be identified in this context:

- It is necessary unique scientific-research infrastructures, which could be included as inseparable part of distributed European scientific-research infrastructures (ESFRI, CERN, etc.) to be established and modernized.

- Bulgarian researchers and scientific-research organizations need better and more systematic support in their efforts to be completely integrated in the European research space, including in regard to the development of the future and newly emerging technologies at European level as well as in regard to their participation in EU scientific research programmes, European technologic platforms, ERA-NET, partners projects and networks.

- Bulgarian researchers need free and convenient access to international data bases for scientific information and publications as far as they could not be completely effective in their research without such access.

In answer to the identified needs of the subject field "Scientific-research activity":

The goal of the planned measures within the frame of OP SESG is to turn the negative trends outlined above and to support the capacity building (infrastructure and human capital) for excellent researches and dissemination of knowledge in the ISSS priority fields. Three inter-supplementing groups of activities would be supported in order to answer the identified problems:

- Enhancing excellent and market-oriented scientific research. OP SESG will support establishment and development of centers of excellence $(\mathrm{CoE})$ and centers of competence $(\mathrm{CoC})$ in the ISSS fields. These centers will answer the necessity of building modern scientific-research complexes, which are directed to the fields of greatest potential for raising the Bulgarian economy competitiveness. The development of capacity for scientific research and innovations will open opportunities for new partnerships with business and for opening new enterprises.

- Improving the territorial and subject distribution if scientific-research infrastructures in regard to the local intelligent specialization. These activities will balance the current excessive concentration of scientific research and capacity financing in the district of Sofia-city, with special focus on regional intelligent specialization. This way, OP would minister for achieving significant and quality applied scientific-research results, processes and services, which are of interest for the business in the relevant region. Investments would be focused on the leading scientific organizations with proved achievements and capacity for development in the ISSS fields, with special stress on establishing partnerships with local business.

The activities will facilitate the transfer of knowledge and good practices from the science and education sector towards the business, and the higher education to become better consistent with the needs of the labour market in regard to highly qualified experts.

- Raising the participation of Bulgarian scientists in international cooperation. Few types of additional activities are planned to be with special focus to distributed European infrastructures, European technologic platforms as well as to projects and networks for European partnership. Aiming active inclusion of Bulgarian researchers in the European scientific space, centers and consortiums with potential for successful participation in the Horizont 2020 Programme will be supported and/or are able to play crucial role in the execution of ESFRI roadmap, when these conditions are combines with ISSS priority directions. OP would support the access to international research centers and data bases as well as publications in recognized scientific magazines, which would give opportunity for internationalization and enhancement of Bulgarian science and economy competitiveness.

The interventions with financing from ERDF and ESF supplement each other in regard to the attraction and development of new generation of highly qualified researchers and experts in the field of SRDA. Under PA1 
(financed by ERDS), the focus would be on attracting the most talented scientists and adaption of their special skills to the applied scientific researches through the prism of ISSS priority fields as well as establishment of excellent conditions for their training through scientific infrastructure modernization. In its turn, PA2 (financed by the ESF) will concentrate on educational system quality and more specifically, will include "horizontal" measures for improving researchers' qualification (for e.g. developing knowledge and skills connected with entrepreneurship, training in intellectual property protection as well as other (general) soft skills that are of significance for all scientists and young teachers), schemes for mobility, career progress as well as actions for encouraging science.

Measures under OP SESG are expected to supplement the national programmes for financing SRDA in the RB. In order the invested funds to be most effectively used, support would be rendered to scientific-research teams with proved and internationally recognized scientific achievements and with potential for development in the ISSS priority fields. The selection would be based on competitive criteria on the grounds of international evaluation of project suggestions, too.

Higher education (HE) system is the second field of intervention, addressed under OP SESG as an important component of scientific-research sector but also as factor for positive impact on the labour market and on the economy competitiveness. It is worth mentioning that HE improvement will have a strong synergetic effect with other measures, planned for strengthening and development the capacity for SRDA, and hence, would render strong impact upon the overall scientific-research and innovation system in the RB. The HE system needs are conditionally grouped the following way.

The number of higher schools projects a problem connected with the balance between resources and quality. The competition of multitude of beneficiaries for limited budget funds turns to be unsatisfying solution. The "weak" participants on the educational market maintain their existence by turning down the thresholds for participating and graduating from bachelor and master programmes. There is lack of serious stimuli for the higher schools to enhance the quality of training and the requirements for the students' performance. This practice closes the vicious circle: poor requirements - deficits in the knowledge and skills - poor realization on the labour market. Graduating in certain professional field very often gets away with the preparedness for work and the level of erudition it imposes.

The visible symptom of the phenomenon is the sharper disproportions between the big number of annual admission and the low number of candidates. This leads to systematic lowering of admission criteria, the number of students grows at the expense of the quality, which, in the end of the day, intensify the inadequacy of education in regard to the labour market needs.

The reform should be considered in direction of optimization, consolidation and reduction of higher school network, while parallel cooperation between education, scientific-research institutes and enterprises is looked for. A vision for development, appropriate legal framework and purposeful financial interventions are necessary for accelerating the process. HE development strategy and the plan for its realization outline the directions for HE reform. OP SESG will support some of the most important elements of this reform such as education quality enhancing and strengthening the connections with the labour market.

Beside result of policies directed also towards change of the profile of the prepared experts in compliance with the development of economy, the contents of the education product is also function of higher schools teachers' qualification. The national programme documents, for example Higher Education Development Strategy (HEDS), outline the need of new skills for work with ICT, digital contents and distant forms of education.

Update of the knowledge in the specific fields of teaching is also necessary. Depending on the subject, this could be realized through cooperation with business in practice-qualification specialties or through participation in scientific work/joint conferences regarding the more academic fields. Teachers should be actively involved in the intellectual life and world trends in their field. The policy of making teachers' academic career more dynamic could be observed as a tool for lifting the prestige of teaching and teacher's motivation.

Narrowing the distance between teachers and their subjects current trends and the binding of academic courses with real professional development so that HE to acquire heavier pragmatic aspect would significantly raise the interest on the behalf of the students.

Ensuring conditions for professional development, finding effective motivation, which to retain perspective young graduates - not only in the country, but also in the universities, should turn into major priority of educational system. In HEDS, „being abreast with the methods of teaching”, „demotivation” and „aging” are pointed to be main weaknesses of teachers. The three factors are mutually grounded. Young people are not 
interested in staying in the HE system and do not see an attractive perspective in academy.

OP SESG possesses potential to turn into turning point for change in the pointed trends. It would give the RB the financial tool to built "new generation of university teachers and researchers, who possess high public prestige, broad language training, high potential for mobility and international scientific cooperation".

Answering the identified needs in subject field „HE system”, OP SESG offers the following financial intervention strategy:

- In regard to the needs, connected with system re-structuring: Complex of measures for improving the systems for management, control and accountancy in the higher schools is planned in compliance with the HEDS. The elaboration and introduction of models for binding financing with the results of training and the realization of the graduates is planned. Support would be rendered for the work of institutions engaged with outside evaluating and accreditation. The role of the rating system at planning the state policy in the field of $\mathrm{HE}$ will strengthen. The operative programme will give stimulus and framework for the necessary HE network re-structuring and optimization.

- In regard to the needs connected with the contents of the educational product: The education in priority for the country fields will be stimulated by a system of scholarships. The introduction of new forms of teaching, the elaboration of integrated programmes and programmes directed towards the needs of the business will be supported.

- In regard to the needs connected with the suppliers of educational service: Possibilities for certified training for work with CIT under internationally recognized standards are set in the OP SESG philosophy. The options for teachers' mobility would be broadened through the principle of supplementing. Specialized programmes for improving the methodic and managerial competencies in the field of HE are planned.

In regard to the need of broadening the scope of the educational service: Through the operative programme possibilities, university students scholarship's system will receive additional resource, which to make studying more accessible and directed towards economy's priority fields. Special attention would be directed towards broadening the possibilities for inclusion of disabled students, Ph.D. candidates and post-graduate students in the HE cycle.

Table 1. Defining the goals in compliance with the needs

A. Development of capacity for scientific-research and development activity (SRDA) in Innovation Strategy for Smart Specialization (ISSS) priority fields

A.1. Needs at national level - increasing the investments in SRDA, with focus on excellent science in the ISSS priority fields

(a) Increasing the investments in SRDAand innovations, and enhancing the excellent scientific achievements

(b) Market-oriented scientific researches for enhancing the capacity for innovations and competitiveness

(c) Investments in modern scientific-research infrastructures and equipment.

A.2. Needs at regional level: Improving the territorial and subject distribution of scientific-research infrastructure in compliance with the regional intelligent specialization

A.3. Needs at institutional and individual level - internationalization of scientific researches as well as attraction and retention of experts in the field of scientific research and high technologies

(a) Internationalization of scientific research.

(b) Attraction and retention of experts in the field of scientific research and high technologies.

Б. HE system:

B.1. Needs connected with the HE system's structure 
B.2. Needs connected with the educational product content (knowledge and skills)

B.3. Needs connected with the educational service suppliers (the Teachers)

B.4. Need of broadening the circle of educational service users ( the ones acquiring $\mathrm{HE}$ )

C. School education, training, life-long learning

C.1. needs connected with the access to school education

C.2. Need of adapting education to the labour market: need of quality and applicable education, creating environment for LLL

C.3. Needs of pedagogic staff

Table 2. Subject goals and investment priorities in OP SESG

\begin{tabular}{|c|c|}
\hline Chosen subject goal & Chosen investment priority \\
\hline $\begin{array}{l}01 \text { - Enhancing scientific-research } \\
\text { activity, development activity in the } \\
\text { field of technologies and } \\
\text { innovations }\end{array}$ & $\begin{array}{l}1 \mathrm{a}-\text { Strengthening the infrastructure necessary for scientific- } \\
\text { research and innovation activity, improvement of the capacity for } \\
\text { realization of achievements in the field of scientific-research and } \\
\text { innovation activity and encouragement of centers of } \\
\text { competence, especially centers of interest for Europe }\end{array}$ \\
\hline $\begin{array}{l}09-\text { Encouragement of social } \\
\text { inclusion, fight with poverty and } \\
\text { each form of discrimination }\end{array}$ & $\begin{array}{l}9 \mathrm{i}-\text { Active inclusion, including with regard to encouraging } \\
\text { possibilities for active participation and better suitability for } \\
\text { employment }\end{array}$ \\
\hline $\begin{array}{l}09-\text { Encouragement of social } \\
\text { inclusion, fight with poverty and } \\
\text { each form of discrimination }\end{array}$ & $\begin{array}{l}\text { 9ii - Social-economic integration of marginalized communities, } \\
\text { the Roma people for example }\end{array}$ \\
\hline $\begin{array}{l}10-\text { Investments in education, } \\
\text { training and vocational training for } \\
\text { acquiring skills and life-long learning }\end{array}$ & $\begin{array}{l}10 \mathrm{i} \text { - Reduction and prevention of premature school leaving and } \\
\text { encouraging equal access to high quality preschool, primary and } \\
\text { secondary education that includes (formal, informal and } \\
\text { individual) ways of learning for second inclusion in the } \\
\text { educational system and the system of training }\end{array}$ \\
\hline $\begin{array}{l}10-\text { Investments in education, } \\
\text { training and vocational training for } \\
\text { acquiring skills and life-long } \\
\text { learning }\end{array}$ & $\begin{array}{l}\text { 10ii - Improvement of the quality and efficacy and access to } \\
\text { higher and equivalent education aiming increasing the } \\
\text { participation and improvement of the levels of education, } \\
\text { particularly for the groups in disadvantaged position }\end{array}$ \\
\hline $\begin{array}{l}10 \text { - Investments in education, } \\
\text { training and vocational training for } \\
\text { acquiring skills and life-long } \\
\text { learning }\end{array}$ & $\begin{array}{l}\text { 10iii - Improvement of the equal access to life-long learning for } \\
\text { all age groups through formal, informal and individual ways, } \\
\text { improvement of knowledge, skills and qualification of labour } \\
\text { force, and encouragement of flexible ways for learning, including } \\
\text { through advising for career development and validation of the } \\
\text { acquired qualification. }\end{array}$ \\
\hline $\begin{array}{l}10 \text { - Investments in education, } \\
\text { training and vocational training for } \\
\text { acquiring skills and life-long } \\
\text { learning }\end{array}$ & $\begin{array}{l}\text { 10iv - Improvement of the adequacy of the systems for } \\
\text { education and training according the labour market, facilitating } \\
\text { the transition from education to work and strengthening the } \\
\text { systems for vocational education and training as well as their } \\
\text { quality, including through mechanisms for envisaging the skills, }\end{array}$ \\
\hline
\end{tabular}


adapting the curricula and establishing and development of systems for learning based on the work, including dual systems of learning and schemes for practice

\section{Financial funds distribution}

Justification for the financial funds (support from the Union) distribution for each of the subject goals and when it is reasonable - for each investment priority in compliance with the requirements for subject concentration, taking into consideration the preliminary evaluation.

The financial funds distribution under the programme is conformed to the possibilities for financing with funds from the European Social Fund (ESF), the European Regional Development Fund (ERDF) and the subject goals (SG) determined in the POartnership Agreement.

OP SESG supports the achievements for all the three pointed subject goals.

\section{PA 1- 243381 138,00 Euro (ERDF)}

Significant part on the funds under PA 1 is expected to be invested in development of centers of excellence and centers of competence as major centers for conduction of high quality scientific researches and innovations in the field of ISSS, and as a supplementing investment in execution of the national goal for 1,5 $\%$ of the GDP, invested in scientific and development activity:

Part of the funds under PA 1 would be invested in scientific-research infrastructure of regional and national significance, for supporting modernization of higher schools and scientific organizations in the ISSS priority fields, in compliance with sub-priority 5.2. Raising the quality and effectiveness of scientific research and innovations (field of impact „Building of scientific and innovation infrastructure”) of the National Development Programme (NDP) „Bulgaria 2020”.

Part of the funds under PA 1 would be invested in measures for development of the capacity for applied researches and innovations in the ISSS priority fields, through support of the researchers in the ISSS fields and their inclusion in the European research space. These measures are in compliance with sub-priority 5.2. Raising the quality and effectiveness of scientific research and innovations (field of impact "Financing the activities for enterprises innovations' research and development”) from NDP „Bulgaria 2020”.

\section{PA 2, IP10i - 121687 467,72 Euro (ESF)}

Significant part of the funds under PA 2 is expected to be invested in measures for achieving the national goal under the Strategy Europe 2020 - reducing the percentage of prematurely left school to $11 \%$.

Part of the funds under PA 2 would be invested in support for mastering key competences. Their intervention has supplementary nature to the national financing at executing sub-priority 1.1 „Ensuring accessible and quality education for personality development through modernizing the education system and ensuring its adaptability regarding the labour market needs” from the National Development Programme „Bulgaria 2020”.

IP10ii - 60191836 , 71 Euro (ESF)

Part of the funds under PA 2 would be directed towards enhancing higher education quality as condition for better realization on the labour market. The intervention would have the nature of supplementary financing regarding the measures planned in the national budget. It is connected with achieving the goals of the mentioned above sub-priority 1.1.

Part of the funds under PA 2 would be used as tool for structural change initiation in the system of the higher schools in Bulgaria. OP resource would financially secure the reform set in the Higher Education Strategy.

Part of the funds under PA 2 would be directed towards support for mechanisms to support the achieving of the national goal under the strategy „Europe 2020” - 36\% of the population between 30 n 34 years to possess completed higher educational degree.

Part of the financing will support activities directed towards enhancing the qualification and human resources' scientific-research careers in the SRDA sector, as a supplement to the interventions under PA1.

IP10iii - 24393 272,6 Euro (ESF)

Part of the resource under PA 2 would be directed towards pedagogical potential qualification. The resource has supplementary nature to the measures executed within the national budget and would contribute to achieving the goals of the above mentioned sub-priority 1.1 . 
Part of the funds under PA 2 would be directed towards supplementary measures for life-long learning development. The measure will contribute to achieving the goals in sub-priority 1.2 Labour power quality characteristics improvement, field of impact "Dynamic adaption of life-long learning and mobility to the personality needs and the labour market requirements” from the NDP „Bulgaria 2020”.

IP10iv - 13037 942,44 Euro (ESF)

The funds under IP10iv, connected with vocational training development would have the characteristics of basic tool for vocational education modernization, set as goal in the National programme for vocational education system modernization.

PA 3, IP9i - 25500000 Euro (ESF)

The funds under IP9i would support the execution of measures for achieving the national goal under the Strategy „Europe 2020” for reducing the number of prematurely left school (up to $11 \%$ ), as well as indirectly - the goal for reducing the number of living in poverty by 260000 people to 2020 .

IP9ii - 84031782 Euro (ESF)

A significant amount of funds under IP9ii from the overall budget under PA is expected as an important financing source in regard to integration of children threatened by exclusion from the educational system for reasons connected with belonging to closed and marginalized ethnic groups. In this sense, the measures under PA 3 would supplement the national financing. Building favourable educational environment would establish preconditions for:

Reducing the number of the dropped out (significant percentage of them belong to the minority groups at risk) and

Better realization on the labour market as a tool for increasing employment and reducing social exclusion.

Both results are in direct relation with the national goals under the Strategy „Europe 2020”: reducing by 260 000 the living in poverty and raising the level of employment to $76 \%$ (2018a-0; 2012a; Dag Aksnes , 2012b; Etzkowitz, Leydesdorff, 1998a; Etzkowitz, 2000a; Gulbrandsen, Slipersaeter, 2007a; Miller, McAdam, McAdam, 2014a; Lemola, 2002a; 2017a-b; 2010a).

\section{CONCLUSION}

Centers of excellence and competence are more than just scientific infrastructure tools. They are a cause that opens new possibilities for quality research, for achieving international recognition and for improving the image of Bulgarian science. In order to be successful, however, they should be competently managed with participation of all interested parties.

\section{REFERENCE LIST}

Centers of Excellence (2018a). http://dg.dk/en/centers-of-excellence-2/.

Centers of Excellence in Research (2018b). http://www.aka.fi/en/research-and-science-policy/centres-ofexcellence/.

Center for Excellence in Research (2018c). https://research.usc.edu/about/vp/cer/.

Centres of Excellence in the Nordic countries, (2012a). Nordic Institute for Studies in Innovation, Research and Education (NIFU), 4/2012.

Dag Aksnes et all. (2012b). Centres of Excellence in the Nordic countries. Nordic Institute for Studies in Innovation, Research and Education (NIFU), 2012, p.8.

Etzkowitz, H., Leydesdorff, L. (1998a). The endless transition: A triple helix of universityindustry-government relations. Minerva, 36, 203-288, 1998.

Etzkowitz, H. (2000a). Tech transfer, incubators probed at triple helix III. Research Technology Management, 43(6): 4, 2000.

Gulbrandsen, M., Slipersaeter, S. (2007a). The third mission and the entrepreneurial university model. In: Bonaccorsi, A., Daraio, C. Universities and Strategic Knowledge Creation. Specialization and Performance in Europe. Cheltenham: Edward Elgar, 2007, pp. 112-143. 
How to Build More Impactful Centers of Excellence, Industry Week, Jun, 17, 2014. (2018d). http://www.industryweek.com/operations/how-build-more-impactful-centers-excellence.

Miller, K., McAdam, M., McAdam, R. (2014a). The changing university business model: a stakeholder perspective, R\&D Management, 44, 3, 2014, p.265-287.

Lemola, T. (2002a). Convergence of national science and technology policies: the case of Finland. Research Policy 31 (2002) pp. 1481-1490 http://blogs.helsinki.fi/changingdynamics/files/2010/09/Lemola_Convergence_of_ST_policies.pdf.

RCUK Executive Directorate delivery plan 2016-2017. (2017a). http://www.rcuk.ac.uk/documents/documents/rcukexecutivedirectoratedeliveryplan-pdf/.

Road map to a Centre of Excellence. (2017b). A business white paper. https://www.hpe.com/h20195/v2/GetPDF.aspx/4AA2-4224EEW.pdf.

The Centre for Excellence in Teaching and Learning through Design CETLD. (2018e). http://arts.brighton.ac.uk/projects/cetld.

Analysis of the state of research in Bulgaria. (2010a), https://www.fni.bg/?q=node/20.

Europe 2020 - flagship initiatives: (2018f). http://ec.europa.eu/europe2020/europe-2020-in-anutshell/flagship-initiatives/index_bg.htm.

Izpalnenie na Plana za deystvie po ISIS. (2018g). (Изпълнение на Плана за действие по ИСИС), https://www.mi.government.bg/bg/themes/inovacionna-strategiya-za-inteligentna-specializaciya-narepublika-balgariya-2014-2020-g-i-proces-na-i-1470-287.html.

Inovatsionna strategiya za inteligentna spetsializatsiya: na Republika Balgariya (2018h). (Иновационна стратегия за интелигентна специализация: на Република България 2014-2020). https://www.mi.government.bg/bg/themes/inovacionna-strategiya-za-inteligentna-specializaciya-narepublika-balgariya-2014-2020-g-i-proces-na-i-1470-287.html.

Natsionalna programa za razvitie: Balgariya 2020. (2018і). (Национална програма за развитие: България 2020), http://www.strategy.bg/StrategicDocuments/View.aspx?ld=765.

Natsionalna patna karta na nauchnata infrastruktura, 2014. (2018j). (Национална пътна карта на научната инфрраструктура, 2014), http://www.strategy.bg/StrategicDocuments/View.aspx?ld=919.

Natsionalna strategiya za razvitie na nauchnite izsledvaniya 2020. (2018k). (Национална стратегия за развитие на научните изследвания 2020), http://www.strategy.bg/StrategicDocuments/View.aspx?lang=bg-BG\&ld=708.

Operativna programa „Nauka i obrazovanie za inteligenten rastezh“ 2014-2020. (2018I). (Оперативна програма „Наука и образование за интелигентен растеж“ 2014-2020), http://sf.mon.bg/?go=page\&pageld=36.

Strategiya „Evropa 2020“ (2018m). (Стратегия „Европа 2020“), http://ec.europa.eu/europe2020/index_bg.htm.

Strategiya za razvitie na vissheto obrazovanie v Republika Balgariya za perioda 2014 - 2020 g. (2018n). (Стратегия за развитие на висшето образование в Република България за периода $2014-2020$ г.), http://www.strategy.bg/StrategicDocuments/View.aspx?ld=962.

Smart Specialisation Platform (20180). http://s3platform.jrc.ec.europa.eu/regions/PT?s3pv=1. 